Canadian University Music Review

Canadian University Music Review Revue de musique des universités canadiennes

\title{
Ezra Schabas. Sir Ernest MacMillan: The Importance of Being Canadian, Toronto, Buffalo, London: University of Toronto Press, 1994. 374 pp. ISBN 0-8020-2849-7 (hardcover) \\ Elaine Keillor. John Weinzweig and His Music: The Radical Romantic of Canada. Composers of North America, no. 15. Metuchen, N.J., and London: The Scarecrow Press, 1994. 317 pp. ISBN 0-8108-2849-9 (hardcover)
}

\section{Gordana Lazarevich}

Volume 16, numéro 2, 1996

URI : https://id.erudit.org/iderudit/1014438ar

DOI : https://doi.org/10.7202/1014438ar

Aller au sommaire du numéro

\section{Éditeur(s)}

Canadian University Music Society / Société de musique des universités canadiennes

ISSN

0710-0353 (imprimé)

2291-2436 (numérique)

Découvrir la revue

Citer ce compte rendu

Lazarevich, G. (1996). Compte rendu de [Ezra Schabas. Sir Ernest MacMillan: The Importance of Being Canadian, Toronto, Buffalo, London: University of Toronto Press, 1994. 374 pp. ISBN 0-8020-2849-7 (hardcover) / Elaine Keillor. John Weinzweig and His Music: The Radical Romantic of Canada. Composers of North America, no. 15. Metuchen, N.J., and London: The Scarecrow Press, 1994. 317 pp. ISBN 0-8108-2849-9 (hardcover)]. Canadian University Music Review / Revue de musique des universités canadiennes, 16(2), 145-149.

https://doi.org/10.7202/1014438ar

All Rights Reserved @ Canadian University Music Society / Société de musique des universités canadiennes, 1996
Ce document est protégé par la loi sur le droit d'auteur. L'utilisation des services d'Érudit (y compris la reproduction) est assujettie à sa politique d'utilisation que vous pouvez consulter en ligne.

https://apropos.erudit.org/fr/usagers/politique-dutilisation/ 
and analysis, sketch study, and a bit of psychology - a classic example of getting "the best illumination for the matter at hand by using as many spots and gels as one can assemble and manipulate" (p. xii).

Without exception, each essay is informative and a pleasure to read. The most technical are the essays from which the book draws its title and the following study of the Tallis Mass. Only "How We Got into Analysis" presumes familiarity with Schenkerian reduction techniques. ${ }^{25}$ The challenge in many of the essays is in absorbing and assimilating all the information offered. This is not intended as a negative comment; Kerman's presentation is clear and well organized, with chapters typically divided into subtopics. But in following his own prescription for a multi-faceted, critical examination of a work, Kerman offers a wealth of approaches and viewpoints. Rather than taking a single, more-or-less direct pathway to understanding a single aspect of a work, the reader is guided along numerous routes, leading to a deeper, broader appreciation. Multiple (at times contradictory) points of view are examined for both strengths and shortcomings in some essays, while in others (notably the Byrd and Beethoven essays) the historical, social, and textual data are all considered as a means of discovering how the composer achieves his musical effects. In short, the book offers one of the same pleasures as the compositions it examines; one can revisit these essays time and again and find new insights at each reading.

Kjellrun Hestekin

Ezra Schabas. Sir Ernest MacMillan: The Importance of Being Canadian. Toronto, Buffalo, London: University of Toronto Press, 1994. 374 pp. ISBN 0-8020-2849-7 (hardcover).

Elaine Keillor. John Weinzweig and His Music: The Radical Romantic of Canada. Composers of North America, no. 15. Metuchen, N.J., and London: The Scarecrow Press, 1994. 317 pp. ISBN 0-8108-2849-9 (hardcover).

As Canada embarks upon the last years that lead toward the end of this century-and indeed the end of the millennium-we are witnessing an awakening interest in our country's cultural and intellectual history. Although ours cannot be measured against that of other cultures that have been developing throughout the millennium, Canada's young cultural story nevertheless is unique and different, due to the geographic, political, and social forces that have shaped this country.

A number of books published over the last decade begin to illuminate the creative energy and the personalities of specific individuals who have provided artistic and intellectual leadership throughout the current century. Information presented through biographies, monographs, and memoirs illuminates our

25 This approachability may be in part a reflection of the strong influence of Tovey, for whom Kerman expresses great admiration. Kerman's essays seem to be targeted, in the main, for Tovey's "naive listener." 
cultural heritage and offers a context for cultural historians of today and of the future to assess the collective creative and intellectual achievements of the 20th century.

A few titles will illustrate the increasing concern with our cultural heritage: Mavor Moore's Reinventing Myself (Stoddard, 1994); David MacKenzie's Arthur Irwin, A Biography (University of Toronto Press, 1993); David Bercuson's True Patriot: The Life of Brooke Claxton, 1898-1960 (University of Toronto Press, 1993); Maria Tippett's Making Culture: English-Canadian Institutions and the Arts before the Massey Commission (University of Toronto Press, 1990); Gordana Lazarevich's The Musical World of Frances James and Murray Adaskin (University of Toronto Press, 1988); and now the books on Sir Ernest MacMillan and John Weinzweig.

Both MacMillan and Weinzweig are towering figures in the evolution of 20th-century musical culture in Canada. Conductor, administrator, adjudicator, educator, composer, organist, and pianist, Sir Ernest was a leading force in this country's musical development over a span of six decades. The cultural institutions that he created and/or developed were, for the most part Torontocentred. However, the thousands of performers, composers, administrators, and educators who have benefited from these institutions have been, and some still are, practising throughout the entire country. Similarly, few Canadian musicians today in their fifties and sixties were not exposed to the teachings and personality of John Weinzweig. Like a vast network, generations of his students are currently teaching in music schools and departments at Canadian universities and abroad. Sir Ernest died in 1973; John Weinzweig is still going strong at age 83. We have not heard the last word from him yet.

These two books collectively provide a solid contribution not only to our understanding of the lives and creative ideals of these two seminal figures, but to the body of knowledge of the 20th-century musical scene in Canada. Ezra Schabas' biography presents a man passionately interested in fostering and producing music, and in cultivating audiences of the future through contact with Canada's youth in music festivals across the country.

As a budding young pianist who had a chance to perform under his baton in the first CBC Music Festival in 1959, the author of this review recognizes in the biography in part a history of her own times. The biography of Sir Ernest MacMillan is indeed a history of the times of many generations of Canadian artists, writers, composers, educators, and performers whose lives and careers were touched in some way by his indefatigable service and sense of responsibility to his country and his people.

Schabas' book constitutes the first biography of this great national musician. It is, therefore, a pioneering work on a pioneering individual, written with empathy for a respected senior statesman. The book presents a compassionate, sensitive, and well-balanced perspective on Sir Ernest's work and personality. As a conscientious biographer Schabas bases his narrative on source materials, keeping the interjections of his own interpretation of the facts down to a minimum. Although this careful approach at times results in the occasional 
section of encyclopedic narrative, Schabas provides a solid working tool for future generations of historians.

Sir Ernest's personality is presented in careful brush strokes and well-documented examples, frequently through quotations by others who knew him. His sense of humour was particularly evident in the annual Christmas Box concerts where "his thespian talents took flight and ... both children and adults split their sides at his antics and those of his musicians" (p. 115). Descriptions of some of the zany antics and slapstick humour make one regret that the Christmas Box concerts predated the video technology era that could have captured these treasured moments for posterity.

Schabas further observes that in MacMillan's own memoirs his "fundamental kindness comes through too, as does his deep affection for his close friends and family, and fondness for people generally" (p. 273). This fondness was especially evident in his interest in children's musical education, be it as adjudicator at festivals or through the annual Toronto Symphony Orchestra (TSO) children's concerts. MacMillan's generosity is illustrated through his offer to have his 1959 pension reduced by $\$ 2,000$ in order to help the TSO players who were having financial difficulties at the time (p. 278). While the book brings out many of the positive aspects of his artistic persona, it does not ignore to mention that its subject was capable of some dramatic temper tantrums.

The book aptly emphasizes MacMillan's accomplishments as a musical nation builder. His twenty-five years as leader of the Toronto Symphony Orchestra transformed it from an amateur organization to one of Canada's leading professional orchestras: from Von Kunitz's Twilight Concerts, for which the musicians received minimal compensation, to a professional organization that served the musicians as a more substantive source of revenue. Although MacMillan had had no prior formal conducting training, he was able to grow as a conductor while simultaneously raising the performance standards, expanding the concert season, and introducing the conservative Toronto audiences to more "daring" repertoire.

His admiration for Wagner's music led him in 1936 to produce the first Toronto performance in concert version of Die Walküre. Due to the length of the work, only the third act was presented. Five years later Toronto was exposed to the first performance of Mahler's Symphony No. 4. Sir Ernest also propagated the cult of Handel's Messiah whose annual performances with the Mendelssohn Choir attested to the solid British orientation of the Toronto public.

The biography affords glimpses into the musical life of Toronto in the 1930s, 1940 s, and 1950s, thereby presenting a basis for the reader's own assessment of the extent to which Sir Ernest contributed to the development of musical activities at the time. Much of the improvement of the working environment for Toronto musicians was directly due to his efforts. His involvement during the post-war reconstruction period in cultural political activism is also well documented in the book. The "March on Ottawa" in 1944 by representatives of the various arts groups included Sir Ernest as a vocal spokesman for 
Canadian music and musicians. The brief presented to a parliamentary committee was a first concerted effort on behalf of the arts groups to articulate the importance of the arts to the Canadian economy. Among other things, it stressed the need for a centralized government body to support cultural activities. This eventually led to the creation of a Canadian Music Council of which MacMillan was the first president.

This was the first of a series of events that led to the creation of a Canada Council, with Sir Ernest providing a strong impetus to each event. His report on the state of Canadian music became part of the Royal Commission Studies, a companion volume to what is now known as the Massey Report. Tabled in Parliament in 1952, this report led to the creation of the Canada Council with Brooke Claxton as the first chairman, and Sir Ernest MacMillan as one of the earliest Council members.

The Canadian Music Council was instrumental in obtaining funding necessary to initiate the Canadian Music Centre (CMC). The resultant commissioning by the CMC of forty-four new Canadian works on the occasion of the centennial celebrations, therefore, presented a high point in the history of Canadian music to that date.

Ezra Schabas is to be commended on his integrity as biographer on this major Canadian musical figure. As happens with all leaders and people with a high national profile, Sir Ernest's activities occasionally resulted in controversy. Schabas treats these with the greatest tact. Chronologically, perhaps, we are still too close to the subject's life and times to be able to arrive at a historical assessment and interpretation of a number of issues surrounding his cultural activities. Future historians will want to take a closer look at his interaction with a number of major Canadian musical figures-other conductors and composers, in particular-including the founders of the Canadian League of Composers. Sir Ernest's enormous correspondence and other papers will need to be published to reveal the human being and the artistic persona in his own words. Contemporary reviews of his concerts will need to be assembled in order to assess the reaction to his artistry by the press and contemporary audiences.

Elaine Keillor's monograph on John Weinzweig constitutes one of a biographical series of volumes on composers of North America. According to the Foreword by the series' editors (John Beckwith, Sam Dennison, William C. Loring, Jr., Margery M.Lowens, and Martha Furman Schleifer) each volume consists of a substantial essay about the composer and a complete catalogue of the compositions. Keillor's book follows the established format of the series, by dividing it into three parts: The Composer; Music; Discography, Filmography, and Bibliography. In her chronological survey of Weinzweig's development as musician, composer, teacher, and administrator, Keillor's biography reveals a young Weinzweig as a radical daring to take on and challenge the conservative, anglophone musical establishment.

He challenged what he saw in the 1930s and 1940s as the domination of Toronto's musical life by musicians originally from German-speaking countries and organists from Britain. Dissatisfied with the derivative, conservative orientation in the musical instruction received at the University of Toronto 
while pursuing his Bachelor's degree, Weinzweig chose to study for his Master's degree at the Eastman School of Music in Rochester under Bernard Rogers. The institution, under the leadership of Howard Hanson, was recognized as a leading centre for advanced composition.

Weinzweig's career evolved parallel to the musical activities of Sir Ernest MacMillan. His-what was for Toronto at the time-unique method of teaching composition, and his avant garde style as the earliest proponent of serialism in Canada, represented a new force on the musical scene. He was the earliest composer whose roots did not extend to the European or British tradition, and the first composer of contemporary music. Like MacMillan, Weinzweig too can be viewed as a musical pioneer of the twentieth century. In his youth, as a somewhat brash composer, he had the personal integrity and temerity to carry out his beliefs and explore new intellectual ideas, despite the pervasive resistance of the conservative audiences. He is viewed by his many students as an excellent, dedicated, and inspiring teacher, responsible for introducing music by Stravinsky, Berg, Schoenberg, Shostakovich, Debussy, and Bartok to his studio.

In her excellent Chapter Six, Keillor summarizes the composer's achievements and contributions to Canadian music, with a thoughtful essay identifying the specifically Canadian features of his style. In an effort to keep the discussion of the composer's life as focused as possible, some of the context for the various musical developments is somewhat sparse. For example, while it is true that with John Beckwith's assistance Weinzweig prepared a proposal that led to the establishment of the Canadian Music Centre in 1959 (p. 46), no mention is made of Sir Ernest's role in the entire process. As stated earlier in this review, Sir Ernest had identified a need for such a centre to serve as a library for the distribution of Canadian works, a decade earlier. As a member of Canada Council at the time it was at his instigation that the Canada Council granted the Canadian Music Council $\$ 60,000$ over a three-year period to launch the Canadian Music Centre (Schabas, p. 268).

The discussion of Weinzweig's works in Part II is terse, succinct, and to the point. It is an intelligent and "user-friendly" approach without embarking upon analytical jargon, yet conveying to the reader the salient structural features of each composition. The catalogue of music lists the essential facts of each work, including its premiere, artists who performed it, and information on publication. The Appendix, listing radio drama programs to which Weinzweig composed music, reveals perhaps the least-known aspect of the prodigious output and eclectic tastes of this composer. Close to 100 compositions in this genre were created for CBC radio between 1939 and 1951. Keillor's book on John Weinzweig successfully achieves the goal of the series which is to inform performers, teachers, and amateurs, and it presents a long-overdue portrait of the composer.

Weinzweig and MacMillan, each in his own way dedicated his life to the propagation of his artistic ideals, in the process enriching our country's musical heritage. We welcome the addition of these two books to the expanding library of Canada's outstanding cultural figures. 